\title{
TRACER TESTS AS A TOOL FOR PLANNING THE MONITORING OF NEGATIVE IMPACTS OF THE MOZELJ LANDFILL (SE SLOVENIA) ON KARST WATERS
}

\author{
SLEDILNI POSKUSI KOT ORODJE ZA NAČRTOVANJE \\ MONITORINGA NEGATIVNIH VPLIVOV ODLAGALIŠČA \\ ODPADKOV MOZELJ (JV SLOVENIJA) NA KRAŠKE VODE
}

\author{
Janja KOGOVŠEK ${ }^{1} \&$ Metka PETRIČ ${ }^{1}$
}

\begin{abstract}
UDC 504.054:556.34.04(497.4)

Janja Kogovšek \& Metka Petrič: Tracer tests as a tool for planning the monitoring of negative impacts of the Mozelj landfill (SE Slovenia) on karst waters

Tracer tests are one of the most useful research methods in karst hydrogeology and they have proved a valuable tool in various applied projects. In recent years we carried out a series of tracer tests, and their results were used as the bases for planning the monitoring of water quality in the influence areas of various pollution sources. In this paper, a case study of tracing at the landfill near Mozelj in southeastern Slovenia is described. The first goal was testing of the functioning of three monitoring boreholes, which were drilled at the margins of the landfill. As often happens in heterogeneous karst systems, they did not intersect the main flow paths from the landfill and are not suitable as monitoring points. On the other hand, the findings about the characteristics of tracer transport in the karst system and outflow through the karst springs were used for identifying the most suitable springs for monitoring and preparing an adequate sampling plan, which should be adapted to hydrological conditions.
\end{abstract}

Keywords: karst water, tracer test, monitoring, landfill, Mozelj, Slovenia.
Izvleček UDK 504.054:556.34.04(497.4)

Janja Kogovšek \& Metka Petrič: Sledilni poskusi kot orodje za načrtovanje monitoringa negativnih vplivov odlagališča odpadkov Mozelj (JV Slovenija) na kraške vode

Sledilni poskusi so ena izmed najbolj uporabnih raziskovalnih metod v kraški hidrogeologiji, pokazali pa so se kot zelo primerni tudi pri reševanju različnih aplikativnih problemov. $\mathrm{V}$ zadnjih letih smo tako izvedli serijo sledilnih poskusov, ki so služili kot strokovna podlaga za izdelavo programa monitoringa kakovosti podzemne vode v vplivnem območju različnih virov onesnaženja. $V$ članku je opisan primer sledenja $\mathrm{z}$ odlagališča komunalnih odpadkov Mozelj v jugovzhodni Sloveniji. Najprej smo testirali reprezentativnosti treh vrtin za monitoring, ki so bile izvrtane na obrobju odlagališča. Kot je zaradi njegove heterogene zgradbe $\mathrm{v}$ krasu pogost primer, vrtine niso zadele glavnih poti pretakanja vod $\mathrm{z}$ odlagališča, zato so kot objekti za monitoring neprimerne. Po drugi strani pa so bile ugotovljene značilnosti prenosa sledila skozi sistem in iztekanja skozi kraške izvire uporabljene kot osnova za izbiro najbolj primernih kraških izvirov za monitoring in za izdelavo ustreznega načrta vzorčenja, ki ga je potrebno prilagoditi hidrološkim razmeram.

Ključne besede: kraška voda, sledilni poskus, monitoring, odlagališče odpadkov, Mozelj, Slovenija.

\section{INTRODUCTION}

Karst aquifers are vulnerable to pollution. Due to strong fissuring and high permeability, the rainwater together with harmful substances enters quickly into the aquifer, and flows through karst channels or open fissures in different directions and toward distant springs. The capac- ity of natural filtration in karst is low and the possible negative influences very likely. In the case of landfills, more dangerous than the wastes themselves is the percolation of wastewater into the karst underground. Due to various contents of refuse, the resulting leachates are

\footnotetext{
${ }^{1}$ Karst Research Institute at ZRC SAZU, Titov trg 2, SI-6230 Postojna, Slovenija, e-mail: kogovsek@zrc-sazu.si, petric@zrc-sazu.si Received/Prejeto: 5.10 .2009
} 
complex liquids with high content of salts, metals and organic compounds (Drew \& Hötzl 1999). The amount and time distribution of precipitation have a major influence on the leachate chemistry (Vadillo et al. 1999). Landfills contribute to a continuous input of contaminants over long periods. Regular monitoring is necessary to assess their possible negative impacts on groundwater.

Hydrogeological research has to define the characteristics of groundwater flow from the landfill, which are the bases for selecting representative monitoring points and preparing a monitoring plan. One of the most suitable methods is tracer tests (Zhou et al. 2002; Eiswirth et al. 1999). Their results help us to define the monitoring points connected to the aquifer. These points include springs and/or boreholes, although the latter are often not representative of the karst aquifer due to its heteroge- neity (Kaçaroğlu 1999; Vadillo et al. 2005). Additionally, due to dynamic responses of karst systems to recharge events, multiple-parameter, long-term, and high-frequency monitoring are required (Zhou et al. 2007). The sampling plan should consider the results of tracer tests to reflect the characteristics of the monitoring locations.

In recent years, we have studied several landfills on Slovene karst (Petrič \& Šebela 2005; Kogovšek \& Petrič $2006,2007)$ in which tracer tests were used. In the article, the case study of the Mozelj landfill near Kočevje in southeastern Slovenia is described. However, the discussion and conclusions additionally consider the results of the above-mentioned projects and our long-term studies on the contaminants transport in the vadose zone (Kogovšek 1987, 1997).

\section{CHARACTERISTICS OF THE STUDY AREA}

The landfill $\left(19,120 \mathrm{~m}^{2}\right)$ is situated near the village Mozelj in southeastern Slovenia on the karst area between the valleys of the Kolpa and Krka Rivers. Since 1973 it has been used as a landfill of non-hazardous wastes of the Kočevje Municipality with approximately 17,000 inhabitants. Based on the existing data, it was not possible to define the position of the water divide between the two rivers, and the drainage pathways of the landfill were not known. Three monitoring boreholes were drilled at the margins of the landfill. The aim of the tracer test was to characterise the groundwater flow in the area and to verify whether the boreholes are representative for monitoring.

\section{HYDROGEOLOGICAL CHARACTERISTICS}

The area (Fig. 1) is mainly composed of carbonate rock, and is dissected with the faults in NW-SE, NE-SW, and $\mathrm{N}-\mathrm{S}$ directions. Jurassic limestone with the inliers of dolomite is dominant in the southern part, while in the northern part Cretaceous limestone with inliers of dolomite prevails. Between the two, Upper Triassic dolomite and Permian clastic rocks are to be found in a narrow belt southeast of Mozelj.

The Rinža River sinks at various locations (depending on hydrological conditions) southeast of Kočevje and flows underground toward the springs in the Kolpa valley. The last ponors, which are reached only during the highest waters, are less than $1 \mathrm{~km}$ distant from the landfill.

In the upper part of the Kolpa valley there are several springs on the left bank (Fig. 1). Larger and perma- nent are the Bilpa (Fig. 2), Dolski potok, Šumetac, and Kotnica springs. In the Krka valley, the most important are the Radešica and Obrh springs. In the past, the Dolski potok and Radešica springs were captured for water supply, but due to a deterioration of water quality they were replaced by other sources.

Tab. 1: Characteristic discharges of the springs (Habič et al. 1990).

\begin{tabular}{|l|c|c|}
\hline Spring & Period & Discharge \\
\hline Bilpa & April to June, 1988 & 0.8 to $5 \mathrm{~m}^{3} / \mathrm{s}$ \\
& $28.9 .2005-24.8 .2007^{*}$ & 0.1 to $35.7 \mathrm{~m}^{3} / \mathrm{s}$ \\
\hline Dolski potok & April to June, 1988 & 1 to $3 \mathrm{~m}^{3} / \mathrm{s}$ \\
\hline Radešica & April to June, 1988 & 0.5 to $23 \mathrm{~m}^{3} / \mathrm{s}$ \\
\hline Obrh & April to June, 1988 & 0.5 to $2.5 \mathrm{~m}^{3} / \mathrm{s}$ \\
\hline
\end{tabular}

* measured by the Environmental Agency

Several tracer tests were carried out in the past (Tab. 2, Fig. 1). As they were done at low waters, the assessed velocities are relatively low, and higher values are to be expected at high waters. Additionally, the tests were carried out almost twenty years ago, so we should be cautious in making the conclusions based on them. The main underground connections were confirmed, while for a more detailed assessment of the characteristics of the water flow from the landfill the results are not sufficient. Namely, in all previous tests the tracers were injected in the sinking streams, while for landfill a diffuse leakage from the surface is characteristic. Percolation through the vadose zone has an important 


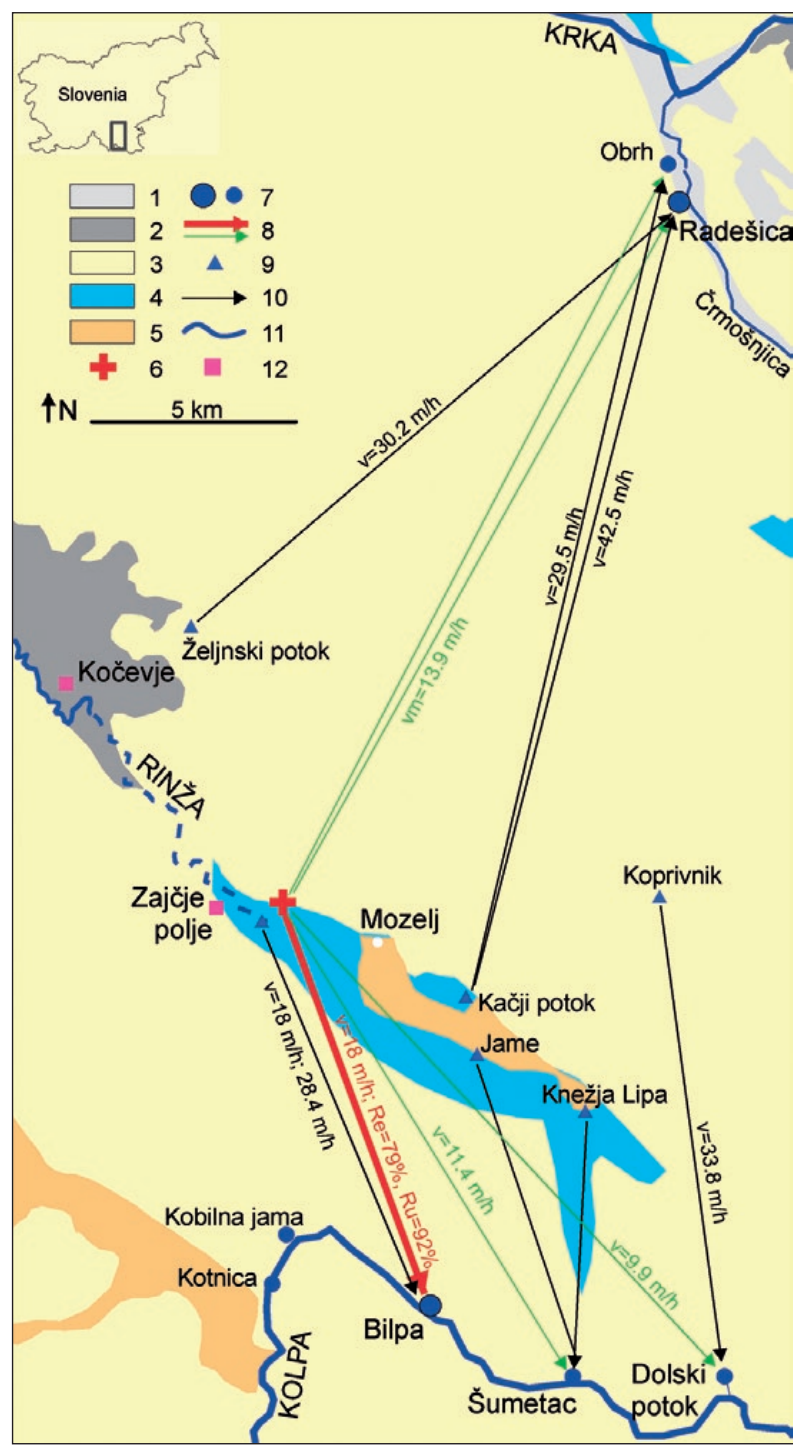

influence on the flow and transport of pollutants. Due to the above facts, an additional tracer test was carried
Fig. 1: Hydrogeological map (Legend: 1. Quaternary river deposits, 2. Quaternary lacustrine sediments, 3. Cretaceous and Jurassic limestone and dolomite, 4. Triassic dolomite, 5. Permian clastic rocks, 6. Landfill-injection point at tracer test in April 2006, 7. Karst spring-sampling point at tracer test in April 2006, 8. Main and secondary underground water connection, proved by tracer test in April 2006, 9. Injection point at previous tracer tests, 10. Underground water connection, proved by previous tracer tests, 11. Surface stream, 12. Precipitation station).

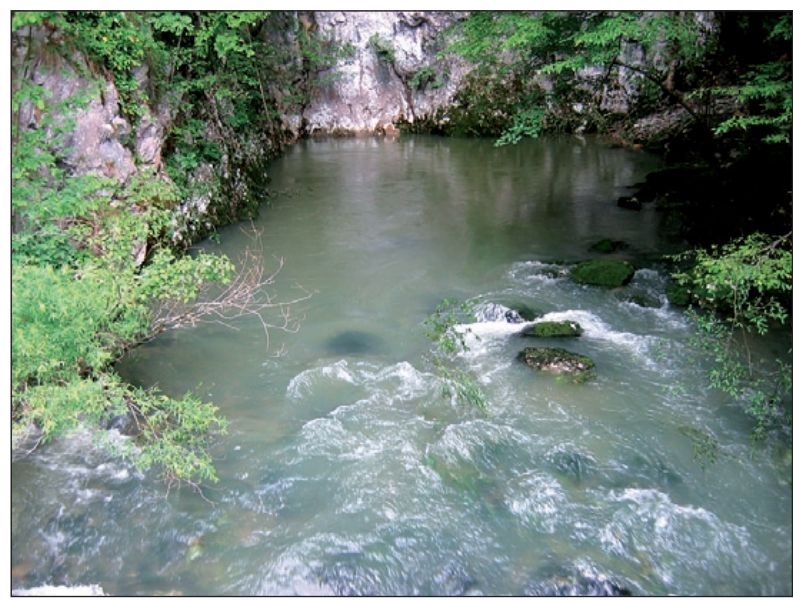

Fig. 2: The Bilpa spring in the Kolpa valley (Photo: M. Petrič).

out with the injection of tracers at the surface near the landfill.

\section{HYDROGEOLOGICAL CHARACTERISTICS OF THE LANDFILL AREA}

Three monitoring boreholes were drilled at the margins of the landfill (Fig. 3); each of them in a different lithostratigraphic unit (Pregl et al. 2004). The northern part (borehole Mo-1) is composed of well karstified, bedded Upper Cretaceous limestone. Toward the southeast it is in a tectonic contact with thick-bedded to massive Lower Cretaceous limestone (borehole Mo-3), which dips gently toward southwest and west. The limestone is tectonically crushed and well karstified. The area south of the landfill is composed of well karstified, thick-bedded to massive Norian-Rhaetian dolomite (borehole Mo-2), which dips toward southwest and west. Below this dolomite lies low-permeable marly and sandy dolomite of 


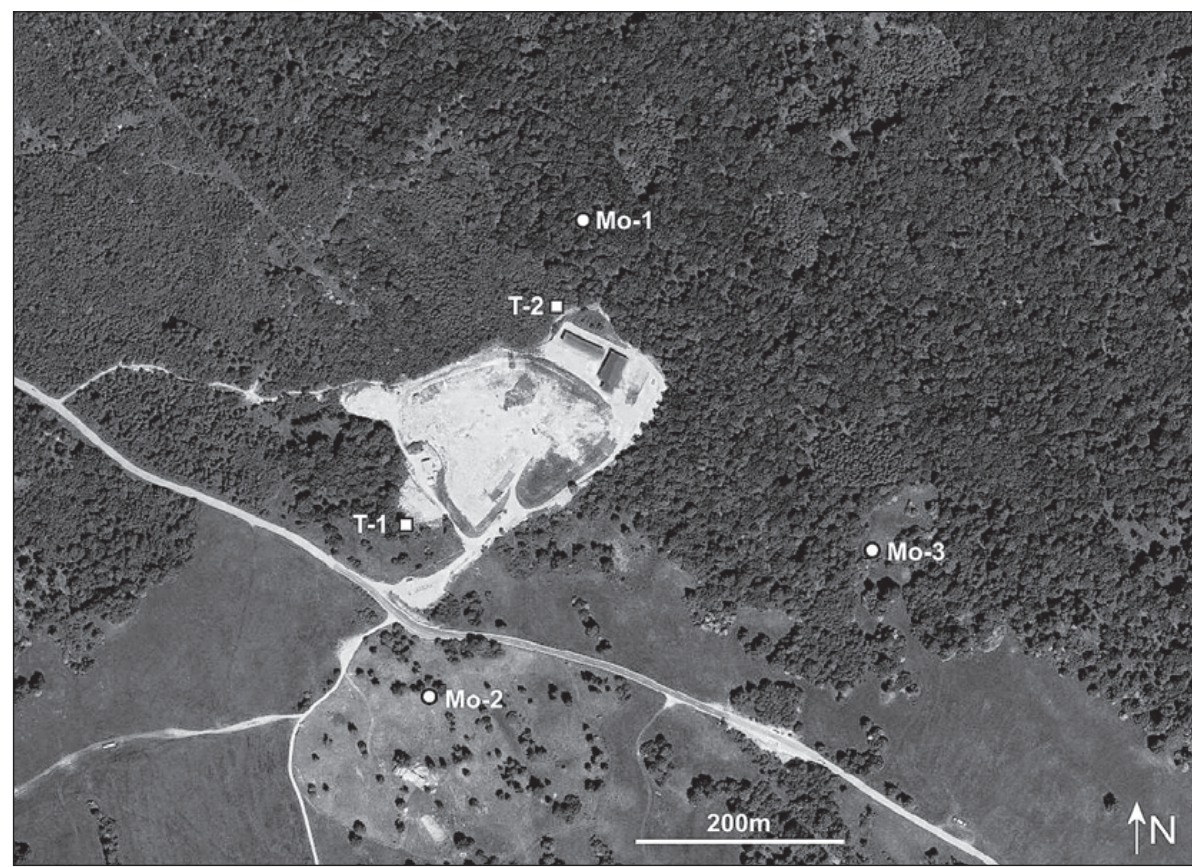

Fig. 3: The Mozelj landfill with the two injection points (T1 and T2) and the monitoring boreholes (Mo-1, Mo-2, Mo-3) (Topographic base: Environmental Agency 2010).
All three boreholes with a depth of approximately $120 \mathrm{~m}$ reached the saturated zone (Pregl et al. 2008). Water levels in them were measured occasionally (8 measurements in the period from 2005 to 2008), therefore only some approximate assessments of their characteristics can be done. The water level is the highest in the borehole Mo-2 (between 411 and $435 \mathrm{~m}$ asl), similar in the borehole Mo-1 (between 413 and $420 \mathrm{~m}$ asl), and the lowest in the borehole Mo-3 (between 389 and $395 \mathrm{~m}$ asl). Based on the comparison of the water levels, the groundwater flow direction toward the east and southeast respectively can be defined. The depth of the

Cordevolian age. The carbonate rocks are covered with thin, often interrupted layers of soil, which have low protection function. vadose zone below the landfill can be assessed at 35 to $70 \mathrm{~m}$. As all measurements were carried out during low or medium waters, the water table is even closer to the surface at high waters.

\section{METHODS}

On April 5, 2006, we installed a rain-gauge Onset RG2$\mathrm{M}$ in the village Zajčje polje (Fig. 1) to measure precipitation at 15-minute intervals (Fig. 8). On September 28, 2005 (data from June 24 to October 4, 2006, are missing due to technical trouble), an automatic gauging station for the measurement of water levels of the Bilpa spring was installed by the Environmental Agency. They provide us with the data on hourly discharges (Fig. 8).

Sampling in the boreholes was done before and during the tracer test by the co-workers of the Institute for Mining, Geotechnology and Environment, who used special sampling bottles. For chemical analysis the water samples were taken at all three boreholes on March 28, 2006, and on April 5, 2006, only in borehole Mo-1. In borehole Mo-3 additional 8 samples were taken during the tracer test. Additionally, we obtained the results of monitoring on September 6, 2005, which were made by order of the landfill manager.
According to the suggestions in the previous hydrogeological report (Pregl et al. 2004) and provisions of the contract with the landfill manager, two different injection points and two different tracers, uranine and eosin, were applied. On April 5, 2006, between 10:30 a.m. and 10:45 a.m., the solution of $18 \mathrm{~kg}$ of eosin was injected at point $\mathrm{T} 1$ at the southwestern border of the landfill and washed off with $5 \mathrm{~m}^{3}$ of water. At the same time, the solution of $18 \mathrm{~kg}$ of uranine was injected at the point $\mathrm{T} 2$ at the northern border and washed off with the same amount of water (Figs. 3 and 6).

Water from the boreholes was sampled in the first three days after the injection, and then additionally on two days after the precipitation event on April 13. In the Bilpa and Radešica springs the samples were taken first at 12-hour intervals, and later once per day with automatic samplers (ISCO 6700). In the Bilpa spring, the fluorescence of the two tracers was additionally measured in situ by a two-channel Fiber-optic Fluorometer 
LLF-M Gotschy Optotechnik at 30-minute intervals. The Dolski potok and Šumetac springs were sampled manually once per day, and later once in each two days. The Kotnica and Obrh springs were sampled only occasionally during weekly control visits. We ended the sampling in May 2007.

eosin on uranine is low. The easiest way to recognize the two tracers is to run a synchronized wavelength change of the excitation and fluorescence monochromators through the spectrum of interest with a constant wavelength distance $\Delta \lambda$ (Käss 2004). However, we were not able to use this method with the Luminescence Spectrometer LS 30, so for the assessment of concentrations a combination of calculations and measurements at lower $\mathrm{pH}$ value, at which the total amount of present eosin and only a small part of uranine can be detected (Käss 2004), was used. For additional verification of the impact of uranine on eosin, we tested several solutions with various concentrations of eosin in the presence of

Fluorescences of uranine $\left(\mathrm{E}_{\mathrm{ex}}=491 \mathrm{~nm}, \mathrm{E}_{\mathrm{em}}=512 \mathrm{~nm}\right)$ and eosin $\left(\mathrm{E}_{\mathrm{ex}}=516 \mathrm{~nm}, \mathrm{E}_{\mathrm{em}}=538 \mathrm{~nm}\right)$ were measured in our laboratory by a Luminescence Spectrometer LS 30, Perkin Elmer. Detection limit for uranine was $0.01 \mathrm{mg} / \mathrm{m}^{3}$ and for eosin $0.05 \mathrm{mg} / \mathrm{m}^{3}$. First measurements were carried out immediately after the sampling and then later when possible suspended particles in the samples were decanted.

Both tracers were detected in the Bilpa spring practically simultaneously; therefore during the analysis some interactions between them occurred. The quantities of the two injected tracers were the same. As in the solutions of equal concentrations the fluorescence of uranine is significantly higher than that of eosin, the impact of uranine on eosin is high, while the impact of uranine, and vice versa. Measured and calculated values were checked by the fluorescence measurements of the mixture of both tracers in various concentrations. Based on the calculations and comparisons the concentrations of the two tracers were evaluated. We are aware of the fact that such approach generates a bigger error.

For parallel measurements with the LLF-M fluorometer we used Em 1 special filter for measurements of uranine in combination with eosin. We made calibrations of the two channels with both tracers and calculated interdependence. In this way measured and corrected values coincide well with the corrected measurements of LS 30 (Fig. 4). The main flow of both tracers toward the Bilpa spring is also confirmed by their very low concentrations in the other observed springs.

\section{RESULTS}

\section{CHEMICAL ANALYSIS OF WATER FROM THE BOREHOLES}

The $\mathrm{Ca} / \mathrm{Mg}$ ratio (normal concentrations of $\mathrm{Ca}$ and $\mathrm{Mg}$ ) was highest in borehole Mo-1 (between 10 and 40), stable around 1.5 in borehole Mo-2, and constant at nearly 3 in borehole Mo-3. We can infer that borehole Mo-1 is mainly recharged from limestone, especially during increased inflow after rainfall. Borehole Mo-2 is located in a dolomite area, and for borehole Mo-3 various inflows from the areas of the two other boreholes are indicated.
This conclusion is in accordance with the measurements of water levels.

Only some minor signs of pollution were detected in the samples from September, 2005 (Fig. 5). In boreholes Mo-2 and Mo-3 the values of nitrates and phosphates were higher, while in borehole Mo-1 a higher value of the total organic carbon-TOC at lowest oxygen saturation (17\%) was measured, which explains high values of TOC and ammonia, and low concentrations of nitrates. Higher oxygen saturation in Mo-2 and Mo-3 (above $80 \%$ ), lower values of TOC and ammo- 
nia, and higher concentrations of nitrates indicate the presence of oxidation processes, which can take place at favourable conditions in this part of the vadose zone (Kogovšek 1987). This indicates differences in short distances within the vadose zone

In the samples from March, 2006, after a precipitation event, the highest concentrations of nitrates (18.8 $\mathrm{mg} / \mathrm{l} \mathrm{NO}_{3}^{-}$) and chemical oxygen demand-COD

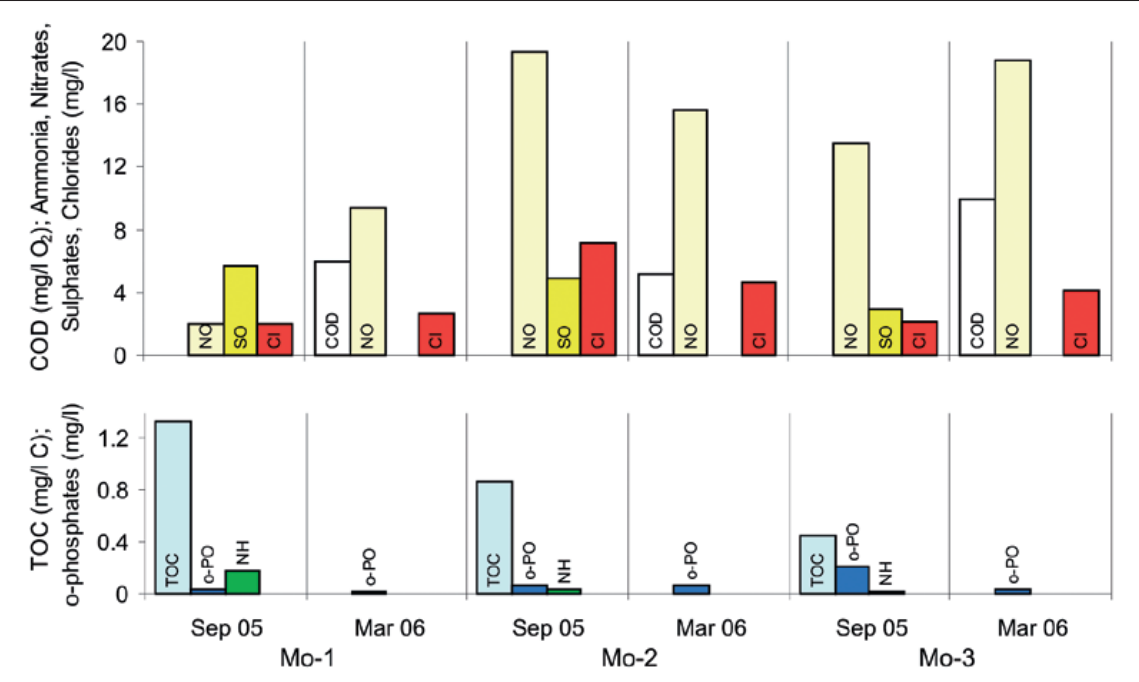

Fig. 5: Concentrations of contaminants in the boreholes (COD-chemical oxygen demand, NH-ammonia, NO-nitrates, SO-sulphates, Cl-chlorides, TOC-total organic carbon, o-PO-o-phosphates). Samples were taken on September 6, 2005, and March 28, 2006 (note that some parameters were measured only for one sampling).

(9.9 mg/ $\mathrm{O}_{2}$ ) were measured in Mo-3, but still the values were relatively low. The pollution is minimal if we compare it with the characteristics of leachates from the Sežana landfill in southwestern Slovenia, which has similar characteristics of a non-hazardous waste disposal (Kogovšek \& Petrič 2007). There in the fresh leachates the organic pollution was high (COD up to $2000 \mathrm{mg} / \mathrm{l} \mathrm{O}$, and biochemical oxygen demand-BOD 5 up to $700 \mathrm{mg} / \mathrm{l} \mathrm{O}_{2}$ ),
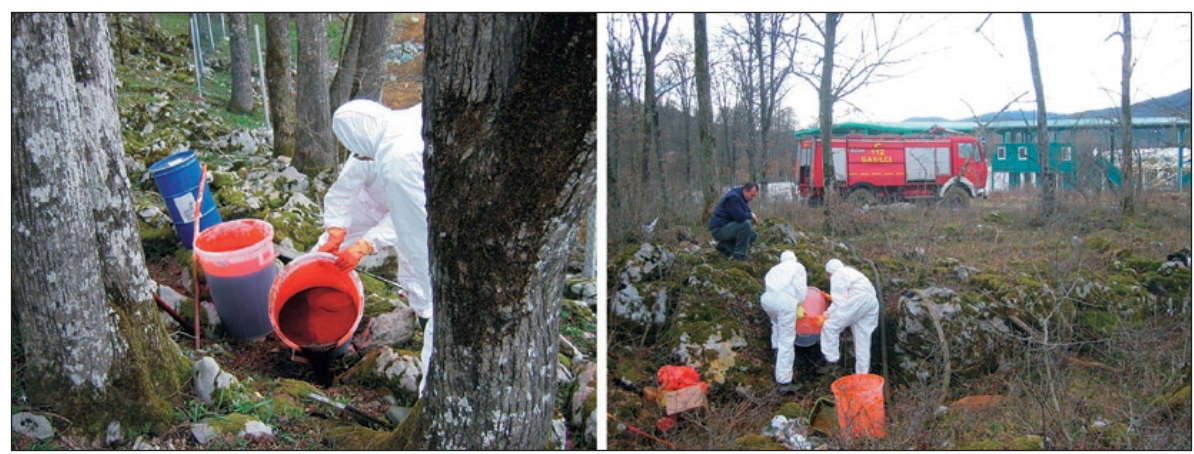

Fig. 6: Injections of eosin (left) and uranine (right) on April 5, 2006 (Photo: M. Petrič).

\section{DETECTION OF \\ TRACERS IN THE BOREHOLES}

In borehole Mo-1 the concentrations of tracers remained around the detection limit. In borehole Mo-2 the uranine concentrations oscillated only slightly above the detection limit, which excludes any connection with the injection point T2 (Fig. 7). The first increase of the eosin concentration on April 5, 2006 at 5 p.m. was probably a reaction to the washing off of the injected eosin with water. A higher concentration was detected on April 6, 2006 at 3 p.m. after rainfall which pushed injected eosin through less permeable fissures toward the borehole Mo-2. In the following period until April 14,2006 , after the appearance of peak concentrations in the Bilpa spring, the eosin concentrations in borehole Mo-2 were below $0.15 \mathrm{mg} / \mathrm{m}^{3}$. We can infer that by this time most of the injected eosin was washed out of the upper, less permeable part of the vadose zone through well permeable fissures which do not intersect borehole Mo-2.

In borehole Mo-3, increased uranine concentrations were detected on April 5 (Fig. 7), probably as a result of washing off with water. The calculated apparent flow velocity of $85 \mathrm{~m} / \mathrm{h}$ is comparable with the fast flow through the most permeable fissures in the vadose zone above the Postojna Cave in southwestern Slovenia in similar hydrological condi- 
tions (Kogovšek 1997). Such high velocities were possible due to the fact that many of the fissures in the vadose zone were temporarily filled with water and hydraulically connected.

Eosin was detected in borehole Mo-3 on April 7, 2006 at 8:35 a.m. following a precipitation event. A similar breakthrough curve with the peak 18 hours before

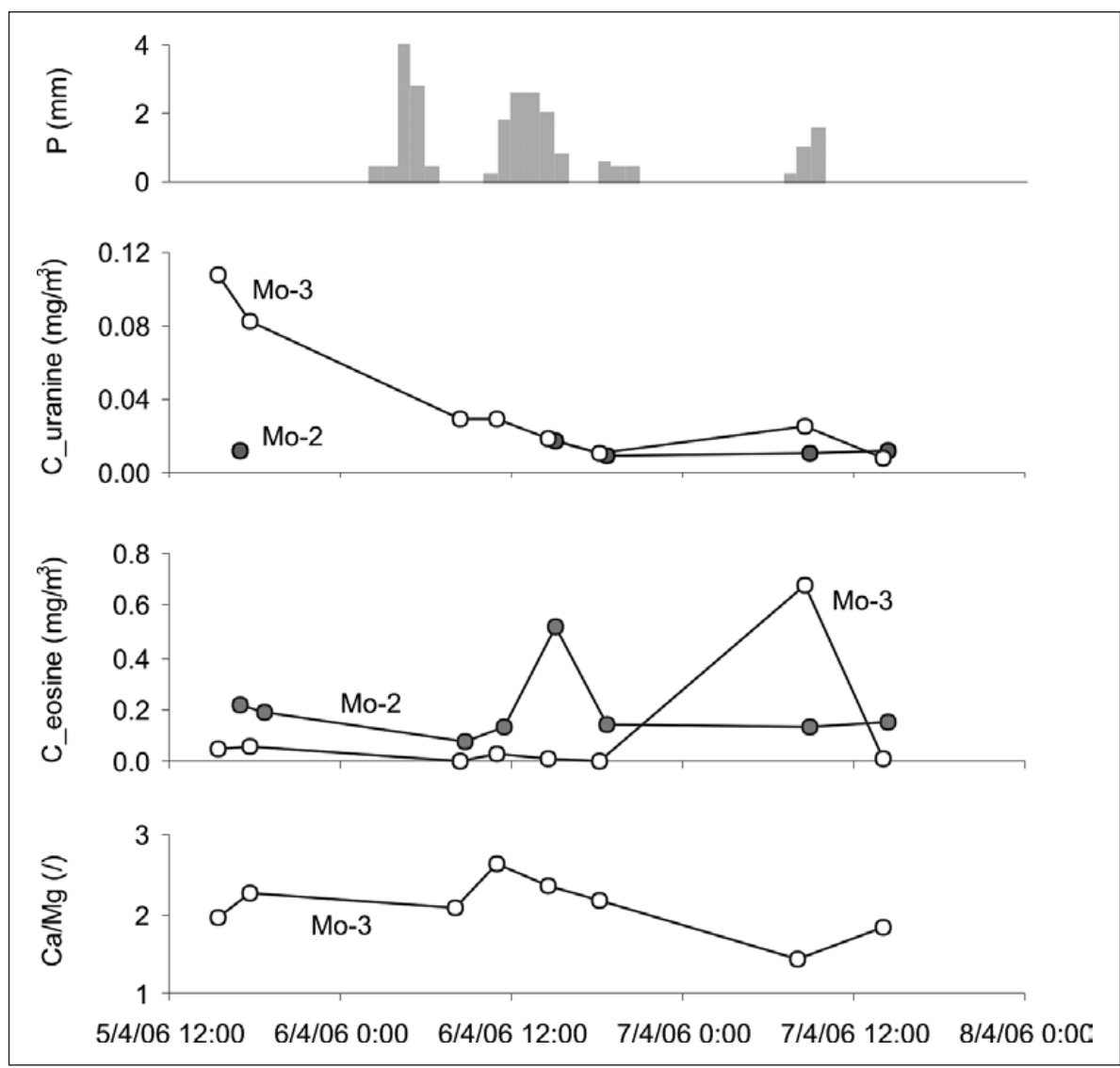

Fig. 7: Precipitation, tracer concentrations and $\mathrm{Ca} / \mathrm{Mg}$ ratios in boreholes $\mathrm{Mo}-2$ and $\mathrm{Mo}-3$.

Tab. 3: The times of detection of tracers ( $t_{m}$ - first detection, $t_{d o m}$ - detection of the maximum concentration) and calculated apparent flow velocities $\left(v_{m}\right.$ - maximum, $v_{\text {dom }}$-dominant).

\begin{tabular}{|c|c|c|c|c|}
\hline Sampling point & $t_{m}$ & $t_{d o m}$ & $\begin{array}{c}v_{m} \\
(m / h)\end{array}$ & $\begin{array}{c}v_{\text {dom }} \\
(\mathrm{m} / \mathrm{h})\end{array}$ \\
\hline \multicolumn{5}{|l|}{ Both tracers } \\
\hline Bilpa spring & 168 hours & 213 hours & 61.4 & 48.4 \\
\hline Dolski potok spring & & 56 days & & 9.9 \\
\hline Šumetac spring & & 56 days & & 11.4 \\
\hline Radešica spring & 56 days & & 13.9 & \\
\hline \multicolumn{5}{|l|}{ Uranine } \\
\hline Borehole Mo-3 & & 4.5 hours & & 85.0 \\
\hline \multicolumn{5}{|l|}{ Eosin } \\
\hline Borehole Mo-2 & 6 hours & 28 days & 31.0 & 6.7 \\
\hline Borehole Mo-3 & & 45 days & & 10.2 \\
\hline
\end{tabular}

was measured in borehole Mo-2. Considering that the distance between boreholes Mo-2 and Mo-3 is $463 \mathrm{~m}$, the apparent velocity of flow between them was $25.2 \mathrm{~m} /$ $h$. This indicates that the underground water connection between the two boreholes is better than between the injection point $\mathrm{T} 1$ and borehole Mo-2 $\left(\mathrm{v}_{\text {dom }}=6.7 \mathrm{~m} / \mathrm{h}\right)$. At the time of increased concentration of eosin in Mo-3 measured lower $\mathrm{Ca} / \mathrm{Mg}$ ratio $(\mathrm{Ca} / \mathrm{Mg}=1.4)$ indicates a more intensive inflow to the boreholes, especially from the dolomite area (Fig. 7).

Nine days after the injection the concentrations of both tracers in all three boreholes were at the detection limit.

\section{DETECTION OF \\ TRACERS IN THE SPRINGS}

The main flow toward the Bilpa spring was proven. By the installed equipment, the uranine was first detected on April 12, 2006 at 10 a.m., and the eosin on the same day at 3 p.m. (Fig. 8). These first appearances were induced by 40 $\mathrm{mm}$ of rain in the conditions when many of the fissures in the vadose zone were temporarily filled with water. The discharge of the spring was in recession, and after the rainfall it increased only slightly. The maximum concentrations of uranine $\left(19 \mathrm{mg} / \mathrm{m}^{3}\right)$ and eosin $\left(12 \mathrm{mg} / \mathrm{m}^{3}\right)$ were detected practically simultaneously on April 14, 2006 at 8 a.m. (Fig. 9). Then they decreased quickly, and persisted at the values slightly above 1 $\mathrm{mg} / \mathrm{m}^{3}$ until the end of April. The peak discharge of $12 \mathrm{~m}^{3} /$ $\mathrm{s}$ was reached after rain (45 $\mathrm{mm}$ ) at the end of April. The concentrations of both tracers decreased, while the amount of recovered tracers increased (Fig. 9). We infer that in this 


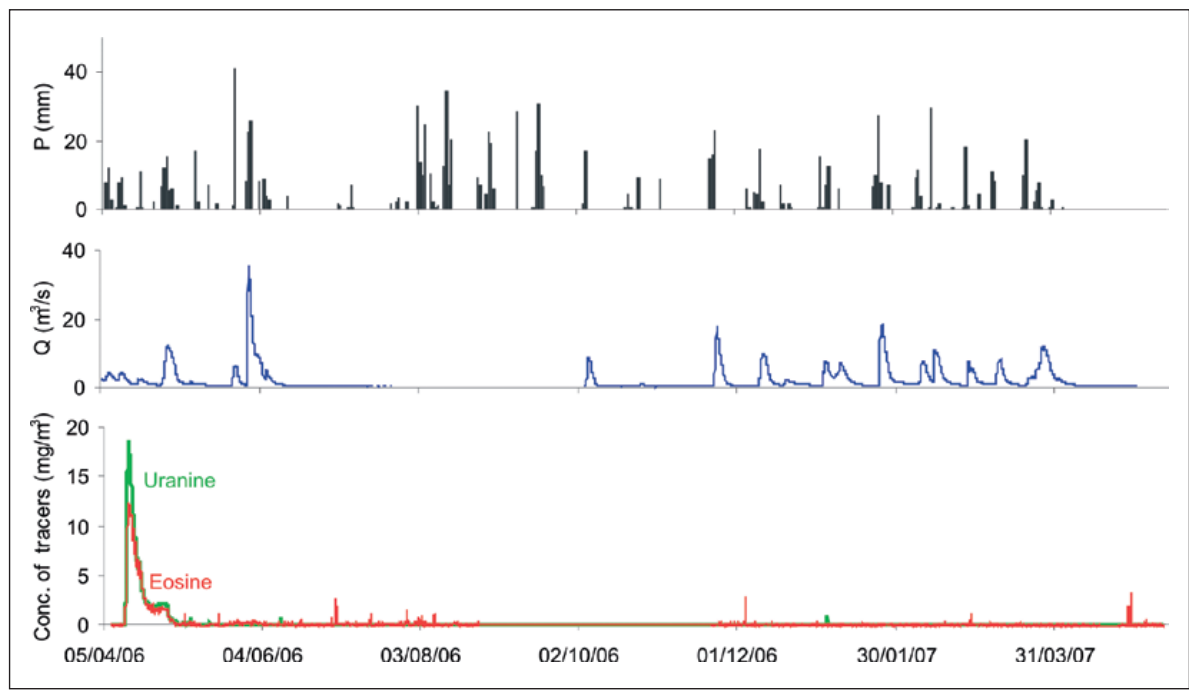

Fig. 8: Precipitation, discharges and tracer breakthrough curves (LLF-M) in the Bilpa spring during the period of 13 months.

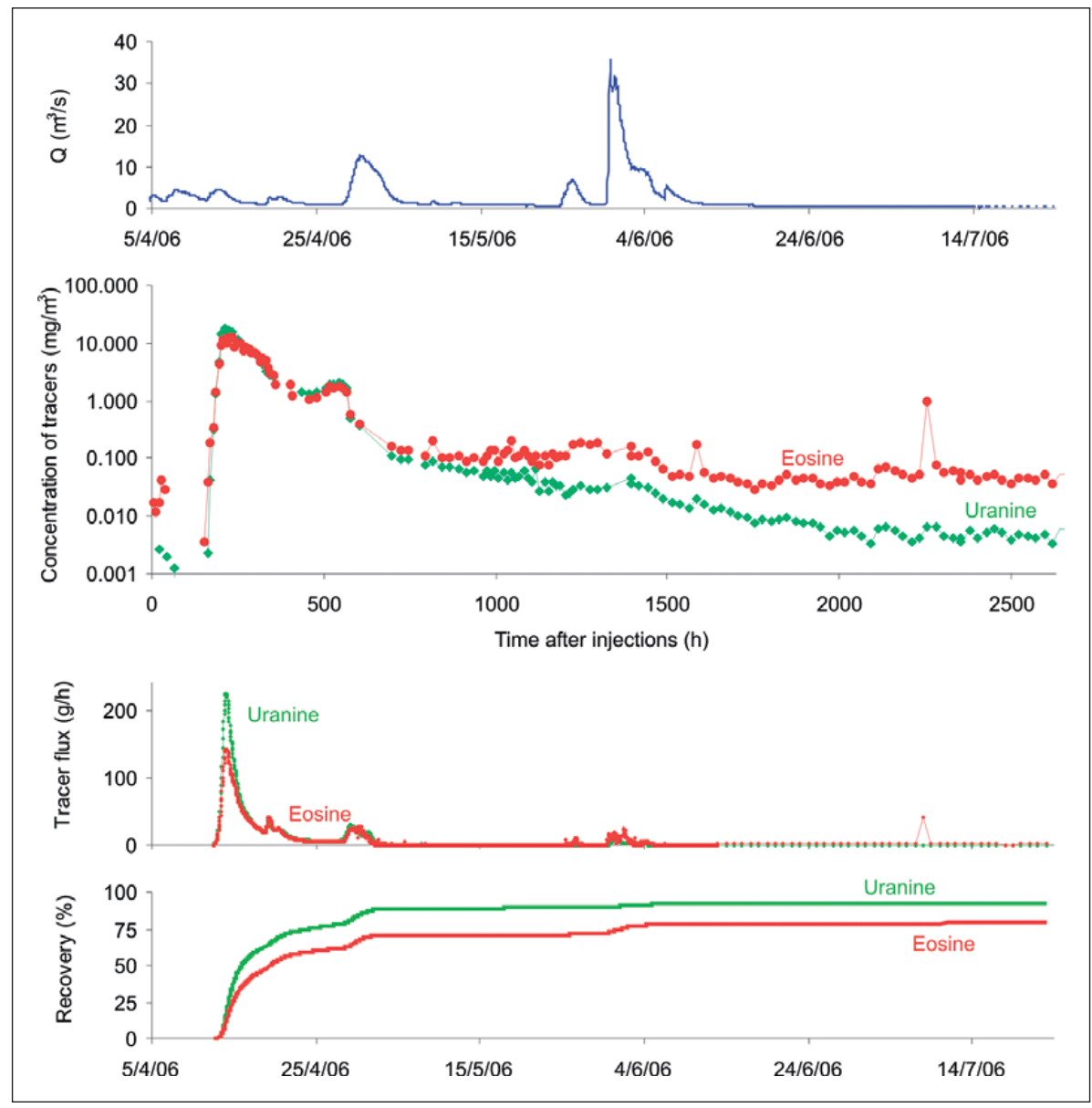

Fig. 9: Discharges and tracer breakthrough curves (LS 30), and the recovery of tracers in the Bilpa spring in the initial period of the tracer test.

period the contribution of the Rinža sinking stream and the primary recharge from the broader catchment area to the discharge of the Bilpa spring was increased. Calculated apparent flow velocities toward the Bilpa spring were practically the same for both tracers (Tab. 3).

Intensive rain during the last week of May (altogether almost $100 \mathrm{~mm}$ ) induced increased outflow of tracers, but parallel with the increase of discharge up to $36 \mathrm{~m}^{3} / \mathrm{s}$ the concentrations decreased. At the end of June, the uranine concentrations dropped below the detection limit, and the eosin oscillated around $0.05 \mathrm{mg} / \mathrm{m}^{3}$.

In the other observed springs the tracers appeared only in low concentrations. In the Dolski potok and Šumetac springs a more significant increase was detected parallel with the discharge increase on May 30, 2006 (Tab. 3). Continuous appearances of eosin (up to $0.1 \mathrm{mg} / \mathrm{m}^{3}$ ) and uranine (up to $0.03 \mathrm{mg} / \mathrm{m}^{3}$ ) were detected in the Radešica spring from the beginning of May 2006 to January 2007 after each more intensive precipitation event (Tab. 3). We can conclude that underground water connections between the landfill and these three springs are possible but weak.

In the period of one week after the appearance of tracers in the Bilpa spring, the main wave of the breakthrough curve was formed in the conditions of discharge recession. Within this interval approximately $70 \%$ of injected uranine and $55 \%$ of eosin were recovered. The main transport of uranine (90\%) and eosin (almost 74\%) was registered in the period from April 13 to May 6 (23 days), when al- 
together $230 \mathrm{~mm}$ of rain of various intensities were recorded after the injection (Fig. 9). Until the end of July 2006, approximately $92 \%$ of uranine and $79 \%$ of eosin were recovered. The calculation of recovery for other springs was not possible because the discharge data were not measured. However, low concentrations of tracers indicate relatively low share of recovery through these springs.

\section{DISCUSSION}

In the monitoring boreholes no significant negative impacts from the landfill were detected by previous chemical analysis of water. No tracers in borehole Mo-1, the appearance of both tracers in borehole Mo-3 in relatively low concentrations, and the absence of uranine in borehole Mo-2 indicate that the majority of injected tracers flowed mainly along the paths which are not intersected by the boreholes. For the uranine calculated apparent flow velocity toward borehole Mo-3 was more than 8times higher than the one for the eosin. Washing off with $5 \mathrm{~m}^{3}$ of water after the injection was sufficient to induce the transport of uranine, while for the transport of eosin some additional rainfall was needed. Low flow velocities of eosin from the injection point T1 toward the nearby borehole Mo-2 indicate that this borehole was drilled in a local low-permeability zone and is out of the main groundwater flow south of the landfill. The results indicate that the three boreholes are not representative for monitoring. This confirms a general finding that in karst monitoring in boreholes is unsuitable in the majority of cases due to the high heterogeneity of karst aquifers.

A preliminary test with injections of water at various locations around the landfill was carried out to compare the capacity of infiltration and to select the injection points. This capacity was low, so we expected longer retention and adsorption of the injected tracers, and even decided to increase the amount of used tracers. However, the tracer test resulted in one high, continuous breakthrough curve in the Bilpa spring without significant oscillations, even though the precipitation inducing this wave was relatively moderate. This indicates high permeability of the karst system observed, but the importance of abundant previous precipitation (and consequently the conditions when a major part of pores and fissures in the soil and vadose zone is temporarily filled with water and hydraulically connected) for a rapid transport of tracers toward the Bilpa spring should be emphasised too. Such conclusion is comparable with the results of detailed researches of hydrodynamics of dripwater and tracer tests on some other test sites on the Slovene karst (Kogovšek 1997; Trček 2007; Kogovšek \& Petrič 2006).
In the phreatic zone the main flow from the landfill converges with the underground flow of the Rinža stream, which sinks east of the landfill. Its maximum discharge of several tens of $\mathrm{m}^{3} / \mathrm{s}$ indicates the existence of large karst channels with high hydraulic gradient of $26 \%$ toward the Bilpa spring. Such concentrated flow is also proved by high recovery rates within the first week of sampling ( $70 \%$ of uranine, $55 \%$ of eosin) and within 23 days after the injection (90\% of uranine, $74 \%$ of eosin) respectively.

Some differences were detected in the transport characteristics of uranine and eosin. In the first part of the breakthrough curve, the amount of detected eosin was lower, while its outflow lasted longer and its concentrations in later periods were higher (Fig. 9). The recovery curve of eosin converges in time with the one of uranine. The reason could be longer retention of eosin in the dolomite area south of the landfill, as well as different characteristics of the two tracers (higher sorption properties of eosin; Käss 2004).

A rapid flow toward the Bilpa spring and high concentrations of tracers confirmed that this spring is the most suitable monitoring point. However, the interpretation of the results of monitoring is difficult, because the Rinža sinking stream, polluted with various pollution sources in the Kočevje area, is also recharging the spring. To assess its influence, a simultaneous monitoring of Bilpa and Rinža is necessary. Furthermore, some characteristic contaminants have to be selected and the monitoring concentrated mainly on them. The monitoring plan should be supported by the measurements of precipitation, discharges and physical parameters of water.

This main underground flow toward the Bilpa spring gets an additional contribution by primary recharge of unpolluted water. It leads to a dilution of contaminants, which is highly influenced by precipitation and hydrological conditions. As a consequence, the water quality of Bilpa is better than that of Rinža. Therefore it is important to measure and compare the inflows from various contribution areas within this complex catchment to interpret properly the results of monitoring. 


\section{CONCLUSIONS}

The described case study, as well as our previous experiences in the study of karst aquifers, shows that tracer tests are a valuable research tool for defining the characteristics of water flow and transport of pollutants in karst systems. Additional information can be gathered by simultaneous measurements of precipitation in the area of injection and physical parameters at springs, as well as by complementary chemical analysis of selected parameters.

Due to specific characteristics of karst aquifers and their high heterogeneity the boreholes are not representative for detecting the pollution of karst waters, and karst springs or other natural objects with water flow should be selected as monitoring points. However, as many karst springs have large catchment areas and complex structures, the overlapping of negative influences from various pollution sources is possible and a good understanding of the functioning of karst aquifers is necessary to interpret the monitoring results.

Based on the results of tracer tests, the most representative monitoring points can be selected, and the influence of various hydrological conditions considered in the construction of the monitoring plan. To increase the possibility of detecting the pollution, it is sensible to sample in the periods when the highest concentrations of pollutants can be expected. During wet periods already medium intensive rainfall would initiate such conditions, while during dry periods a more intensive precipitation is needed. In dry conditions rainwater is first used to saturate deposited waste and the soil; only then do leachates infiltrate into the vadose zone and then further on toward the spring. Especially during long summer droughts, when precipitation water is only stored in wastes, soil and vadose zone, the waste water from the landfill does not reach the springs. Only sufficiently intensive precipitation in the following period induces the leaching of contaminants out of the landfill and pushing of the previously stored contaminants from the vadose zone toward the phreatic zone. From there the transport to the springs is very rapid. As the conditions in karst aquifers change quickly, it seems the most efficient to take several samples in the time of a complete water wave: from the beginning of the increase of discharge, through the discharge peak, and in the recession phase back to the initial state. To avoid strong dilution, it is better not to sample in conditions of very high discharges.

\section{ACKNOWLEDGEMENT}

The tracer test was supported by the Institute for Mining, Geology and Geotechnology from Ljubljana, and the public company Komunala Kočevje which is the landfill manager. Additionally, we would like to thank the Environmental Agency of the Republic of Slovenia for giving us the hydrological data free of charge. We are grateful for the valuable review comments and suggestions from Vivian Gremaud, Ralf Benischke, and one anonymous reviewer, and the editor Nico Goldscheider. We thank Trevor Shaw for the revision of the English language.

\section{REFERENCES}

Drew, D. \& H. Hötzl (eds.), 1999: Karst Hydrogeology and Human Activities.- A.A. Balkema, pp. 322, Rotterdam, Brookfield.

Eiswirth, M., Hötzl, H., Jentsch, G. \& B. Krauthausen, 1999: Contamination of a karst aquifer by a sanitary landfill.- In: Drew, D. \& H. Hötzl (eds.) Karst Hydrogeology \& Human Activities. A.A. Balkema, 163-167, Rotterdam, Brookfield.
Environmental Agency, 2010: Environmental Atlas.[Online] Available from: http://gis.arso.gov.si/atlasokolja [Accessed 11 $1^{\text {th }}$ March 2010].

Gams, I., 1965: Aperçu sur l'hydrologie du karst Slovene et sus communications souterraines.- Naše jame, 7 , $1-2,51-60$.

Habič, P., Kogovšek, J., Bricelj, M. \& M. Zupan, 1990: Izviri Dobličice in njihovo širše kraško zaledje.Acta carsologica, 19, 5-100. 
Kaçaroğlu, F., 1999: Review of groundwater pollution and protection of karst areas.- Water, Air, and Soil Pollution, 113, 337-356.

Käss, W., 2004: Geohydrologische Markierungstechnik.Gebrüder Borntraeger, pp. 557, Berlin, Stuttgart.

Kogovšek, J., 1987: Natural purifications of sanitary sewage during the vertical percolation in Pivka jama.Acta carsologica, 16, 121-139.

Kogovšek, J., 1997: Pollution transport in the vadose zone.- In: Günay, G. et al. (eds.) Karst waters \& environmental impacts : proceedings. A.A. Balkema, 161-165, Rotterdam, Brookfield.

Kogovšek, J. \& M. Petrič, 2006: Tracer test on the Mala gora landfill near Ribnica in south-eastern Slovenia.- Acta carsologica, 35, 2, 91-101.

Kogovšek, J. \& M. Petrič, 2007: Directions and dynamics of flow and transport of contaminants from the landfill near Sežana (SW Slovenia).- Acta carsologica, 36, 3, 413-424.

Novak, D. \& J. Rogelj, 1993: Hidrogeološke raziskave zaledja izvira Šumetac ob Kolpi.- Geologija, 35, 319328.

Petrič, M. \& S. Šebela, 2005: Hydrogeological research as a basis for the preparation of the plan of monitoring groundwater contamination - a case study of the Stara vas landfill near Postojna (SW Slovenia).Acta carsologica, 34, 2, 489-506.

Pregl, M., Juvan, G. \& B. Ivačič, 2008: Poročilo o monitoringu dinamike podzemne vode na območju odlagališča odpadkov Mozelj za leto 2007.- Report, IRGO, Ljubljana.
Pregl, M., Tancar, M. \& B. Čenčur Curk, 2004: Hidrogeološko poročilo območja predvidenega vpliva deponije Mozelj in možnosti izvajanja monitoringa onesnaženja podzemnih vod.- Report, IRGO, Ljubljana.

Trček, B., 2007: How can the epikarst zone influence the karst aquifer hydraulic behavior?- Environmental Geology, 51, 5, 761-765.

Vadillo, I., Andreo, B. \& F. Carrasco, 2005: Groundwater contamination by landfill leachates in a karstic aquifer.- Water, Air, and Soil Pollution, 162, 143-169.

Vadillo, I., Carrasco, F., Andreo, B., Garcia de Torres, A. \& C. Bosch, 1999: Chemical composition of landfill leachate in a karst area with a Mediterranean climate (Marbella, southern Spain).- Environmental Geology, 37, 4, 326-332.

Zhou, W., Beck, B.F., Pettit, A.J. \& B.J. Stephenson, 2002: A groundwater tracing investigation as an aid of locating groundwater monitoring stations on the Mitchell Plain of southern Indiana.- Environmental Geology, 41, 842-851.

Zhou, W., Beck, B.F. \& J. Wang, 2007: Groundwater monitoring for cement kiln dust disposal units in karst aquifers.- Environmental Geology, 52, 761-777. 